\title{
IMPLEMENTASI PENDIDIKAN ISLAM MASA NABI MUHAMMAD SAW
}

\author{
Andi Nova, M. Pd \\ novaa0874@gmail.com
}

\begin{abstract}
Abstrak
Tujuan penelitian ini adalah ingin menggambarkan tentang bagaimana implementasi pemdidikan Islam pada pada Nabi Muhammad SAW. Untuk mengungkapkan hal itu, peneliti menggunakan metode penelitian library research dengan jenis penelitian analisis sejarah dan tekhnik pengumpulan data diambil dari berbagai literatur yang membahas tentang tema yang dimaksud. Data yang sudah dikumpulkan kemudian di analisis dengan menggunakan teknik content analisis. Hasil penelitian mengungkapkan bahwa dari berbagai metode yang dilaksanakan Rasulullah Saw dalam pengimplementasian Pendidikan Islam yang paling diminati peserta didik yaitu metode Uswah (Suri teladan yang baik), walaupun pada dasarnya dari seluruh metode yang ditawarkan mempunyai kelebihan masing-masing dan tujuannya pasti baik. Fokus utama ketika di Makkah menanamkan Pendidikan Tauhid, dalam merubah karakter peserta didik diutamakan berubah dulu kepercayaannya sebab perubahan menuju lebih baik itu hannyalah dengan melakukan pembersihan terlebih dahulu melalui jalur Tauhid. Mengingat latar belakang awal kondisi Masyarakatnya penyembah berhala, hobi membunuhi anak perempuan, berjudi dan sebagainya. Sesudah di Madinah penanaman nilai Pendidikan sudah mulai terlihat hasil secara nyata disebabkan sudah banyak pengikut loyalitas tinggi tanpa dikhawatirkan lagi konsistensinya.
\end{abstract}

Kata Kunci: Muhammad, Islam, Pendidikan

\section{PENDAHULUAN}

Saudi Arabia saat ini merupakan Negara yang menjadi saksi atas turunnya berbagai macam perintah berupa wahyu kepada Nabi Muhammad Saw. Mengingat masa itu kondisinya sangatlah memprihatinkan sehingga sudah sewajarnyalah dikatakan dengan istilah zaman jahiliyah (masa kebodohan). Secara intelektual bukan berarti Sumber Daya Manusia (SDM) waktu itu mengalami kebodohan akan tetapi jahiliyah yang dimaksud dalam hal ini keterpurukan akhlak dan moral manusia mengenai ketauhidan dan memastikan siapa Tuhan yang sebenarnya untuk disembah. Sebab keterpurukan dalam hal ketauhidan maka dengan sendirinya akhlak dan moral masyarakat arab waktu itu dikategorikan sangat buruk, hal yang demikian dengan pembuktian sejarah kebiasaan main judi, membunuh bayi perempuan, perang antar suku, penyembahan terhadap berhala dan lain sebagainya. Sebab latar belakang tersebut maka muncullah manusia yang bernama

Al-Madrasah: Jurnal Ilmiah Pendidikan Madrasah Ibtidaiyah Vol. 6, No. 1, Januari-Maret 2022 
Muhammad Saw dengan nuansa perbaikan moral masyarakat Arab melalui Pendidikan keislaman.

Sesudah Nabi Muhammad Saw diangkat menjadi seorang Rasul waktu umur 40 tahun, disinilah permulaan menjalankan tugasnya menyampaikan yang hak, risalah dan wahyu Allah Swt kepada manusia khususnya penduduk Makkah yang menjadi domisili, dimana pengangkatan sebagai seorang Rasul itu merupakan suatu wahana untuk melaksanakan implementasi Pendidikan Islam pada masyarakat sekitarnya dibuktikan dengan sikapnya mulai dari sejak mudanya sudah mulai menanamkan nilai-nilai pendidikan terhadap semua orang yang bertemu dengannya. Bagaimana tidak, Rasul yang selalu mewarnai dan tidak terpengaruh sedikitpun dengan kenakalan anak seusianya dan bagaimana saat beliau sangat dimuliakan oleh kakeknya Abdul Muthalib sehingga tidak ada yang berani duduk di Kursi milik kakeknya kecuali Nabi Muhammad Saw. Secara mendasar hal yang demikian suatu hal yang berkaitan dengan Pendidikan Hikmah yang bisa dipetik berbagai kebaikan.

Banyak praktik Pendidikan telah dilakukan Rasulullah Saw kepada ummatnya, pemberian contoh suri tauladan yang baik berupa perkataan, tingkah laku, ciri khas dakwahnya yang semuanya itu memberikan sinyal-sinyal nuansa Pendidikan. Berbagai hal yang demikian yang membuat ketertarikan untuk membahas kembali dalam tulisan ini walaupun sudah banyak yang melakukan penelitian. Adapun rumusan yang akan dipaparkan mengenai Penugasan Muhammad Saw menjadi Rasul, Penanaman Nilai Pendidikan Islam Secara Sembunyi, dan secara terang-terangan, Pelaksanaan Pendidikan Islam di Makkah dan Madinah. Sesuai dengan yang dirumuskan sub bahasannya maka sudah secara otomatis hal yang demikian akan menjadi sebagai alasan untuk melakukan penelitian ini.

\section{METODE PENELITIAN}

Penelitian ini menggunakan Metodologi Study Pustaka (library research) dengan memanfaatkan kumpulan buku yang sudah tersedia di Perpustakaan baik secara manual maupun secara online. Berbagai hasil bacaan dari berbagai literatur baik elektronik buku, jurnal, catatan maupun hasil penelitian terdahulu yang sudah tidak sedikit menelitinya maka terbentuk dan muncullah analisis yang dituangkan dalam bentuk tulisan. Dan sebagai sumber yang dipakai dalam mengumpulkan data menggunakan data sekunder, 
menggunakan data sekunder sebab keterbatasan jarak tempuh yang tidak memungkinkan peneliti untuk melakukan study lapangan dan kondisi saat ini belum pulih $100 \%$ dari pandemi.

\section{HASIL DAN PEMBAHASAN}

\section{Penugasan Muhammad Saw menjadi Rasul}

Makna dalam ruang lingkup kecil dari pengertian pendidikan ialah terjadinya proses perubahan sikap dan tingkah laku seseorang ataupun kelompok dalam usaha agar mendewasakan manusia dalam upaya pengajaran dan pelatihan. ${ }^{1}$ Definisi lainnya menjelaskan bahwa pendidikan ialah mengembangkan kepribadian hingga menanamkan rasa tanggung jawab sehingga pendidikan terhadap manusia seperti fungsi makanan yang dapat memberi kekuatan, keafiatan, dan pertumbuhan agar mempersiapkan penerus yang menjalankan kehidupan guna mencukupi tujuan hidup secara efektif dan efisien. ${ }^{2}$

Pendidkan dapat dilihat dari tiga kriteria: pendidikan sebagai trasformasi belajar mengajar, pendidikan sebagai riset ilmiah dan pendidikan sebagai suatu lembaga pendidikan. Adapun pendidikan dikatakan sebagai transformasi belajar mengajar karena dalam prosesnya melibatkan pendidikan (guru) sebagai tenaga pengajar dan siswa sebagai peserta didik. Kemudian pendidikan dikatakan sebagai riset ilmiah karena pendidikan merupakan suatu objek penelitian ilmiah. Ruang lingkup dalam penelitian cukup banyak seperti fakta dan kenyataan pendidikan yang terjadi di lapangan hingga ranah filosofi sebagai acuan untuk mengambangkan keilmuan. Adapun pendidikan merupakan sebagai suatu lembaga pendidikan karena pada dasarnya sering dijumpai istilah yang selalu mengarah dengan lembaga yang disebut sekolah, madrasah ataupun perguruan tinggi yang melaksanakan kegiatan pembelajaran. ${ }^{3}$ Dapat dipahami dalam ranah keislaman ketika dikolaborasikan dengan Pendidikan, bahwa Pendidikan yang berdasarkan ajaran Islam atau tuntunan agama Islam sebagai usaha untuk membina dan membentuk kepribadian yang bernuansa kepada Alquran dan Sunnah Rasulullah Saw, sebab tanpa adanya Pendidikan yang berkiblat kepada keislaman maka moral dalam suatu Masyarakat akan terpuruk.

\footnotetext{
Ahmad Asrori, Reorientasi Ilmu Pendidikan Islam Dari Paradigma Klasik Hingga Kontemporer (Yogyakarta: Cetta Media, 2014), 42.

${ }^{2}$ Syamsul Kurniawan, Pendidikan Karakter (Yogyakarta: Ar-ruzz Media, 2013), 27.

${ }^{3}$ Muliawan, Ilmu Pendidikan Islam (Jakarta: Raja Grafindo Persada, 2015), 13.
} 
Keterpurukan Moral yang terjadi pada Masyarakat sekitarnya dan Nabi Muhammad Saw menyadari akan hal tersebut, mengasingkan diri ke Gua Hira sebagai solusi. Lalu turunlah ayat perdana Q.S al-Alaq ayat 1 - 5 sebagai pertanda diangkatnya Muhammad Saw menjadi seorang Rasul. Dalam Surat ini terlihat bahwa belum ada seruan kepada Rasulullah untuk menyeru manusia kepada Agama Islam. ${ }^{4}$ Sesudah Malaikat Jibril turun perdana, dengan waktu yang lama Jibril tidak muncul lagi yang menyebabkan Rasulullah Saw terheran dan selalu menunggu apa instruksi selanjutnya. Berkunjung dan mendatangi Gua Hira sudah menjadi suatu kebiasaan, terdengarlah bunyi suara dari langit lalu diangkatnya kepala ke atas terlihatlah Malaikat Jibril. Menyaksikan dengan mata kepala sendiri. Lalu Rasulullah Saw gemetaran dan ketakutan dan menyuruh Khadijah untuk menyelimutinya. Hal yang demikian sebagai latar belakang turunnya Surat al-Muddatsir ayat 1 sampai 7 .

Ayat tersebutlah yang akhirnya menjadi sebagai SOP (Standard Operational Prosedure) agar mengajak umat manusia menyeru Allah Swt dengan mengutamakan uswatun hasanah (suri tauladan yang baik) kepada orang yang ditanamkannya nilai-nilai Pendidikan keislaman. Tahap awal tidak terlalu banyak yang mengikuti sebab namanya sebuah ajakan yang mengandung nilai pendidikan kebiasaannya membutuhkan proses. Namun, pada fase inilah suatu proses Pendidikan Islam dimulai, dimana Rasulullah Saw mendidik para sahabatnya supaya senantiasa menjaga keimanannya kepada Allah Swt.

\section{Penanaman Nilai Pendidikan Islam Secara Sembunyi}

Sesudah turunnya perintah untuk mengajak manusia menuju Agama Allah, selanjutnya Rasulullah Saw mulai mengajak kerabat terdekat dan para sahabat. Fase ini sudah menarik beberapa sahabat untuk ikut bergabung dalam satu barisan, Sesudah itu para sahabat ini menjadi objek untuk penanaman nilai-nilai Pendidikan Islam atau dengan istilah lain dikatakan sebagai peserta didik. Diajarkan dan diseru tentang berbagai dasar ajaran Islam yaitu beriman kepada Allah Swt dan meninggalkan berhala. Diantaranya yang berhasil dikader yaitu isteri beliau, 'Ali bin Abi Thalib, Zaid bin Tsabit dan Abu Bakar asShiddiq. Karena kedekatan Abu Bakar kepada Rasulullah Saw, maka ketika disampaikan seruan tentang ajaran Islam beliau langsung beriman dan percaya sepenuhnya tanpa ada sedikit pun keraguan. Bahkan melalui wasilah Abu Bakar banyak orang yang masuk Islam yang pada akhirnya diberikanlah gelar “Assabiqunal Awwalun” yaitu orang yang terlebih

\footnotetext{
${ }^{4}$ A Syalabi, Sejarah dan Kebudayaan Islam (Jakarta: Al-Husna Zikra, 1997), 83.
}

Al-Madrasah: Jurnal Ilmiah Pendidikan Madrasah Ibtidaiyah Vol. 6, No. 1, Januari-Maret 2022 
dahulu mengakui kebenaran Islam. Diantara nama-nama tersebut adalah 'Usman bin 'Affan, Zubeir Ibnu 'Awaam, Sa'ad Ibnu Abi Waqqash, 'Abdurrahman bin 'Auf, Thalhah Ibnu 'Ubaidillah, Abu 'Ubaidah Ibnul Jarrah dan al-Arqam Ibnu Abil Arqam. Mereka adalah para peserta didik yang diajarkan tentang agama Islam yang pada akhirnya menjadi cikal bakal seorang Pendidik juga dan sebagai penerus estafet perjuangan.

Melalui orang-orang dan sahabat yang masuk Islam tersebut Rasulullah Saw terus menerus melakukan pembinaan dan Pendidikan ketauhidan sehingga pada akhirnya terbentuklah karakter-karakter sahabat yang siap membela dan mempertahankan Agama Islam bahkan siap mengorbankan nyawanya sekalipun. Tujuan Pendidikan Islam salah satunya yaitu menghambakan diri kepada Allah Swt. Maka manakala seorang sahabat yang dididik oleh Pendidikan Islam telah mampu menghambakan dirinya untuk Islam, merelakan harta jiwanya maka dapat dikatakan tujuan Pendidikan saat itu kategori sudah tercapai. Salah satu kisah sahabat yang merupakan contoh didikan tersebut adalah seperti halnya Bilal bin Rabah yang disiksa sedemikian parahnya, namun tetap berpegang teguh bahwa hanya Allah yang maha Esa. Dan masih banyak contoh sahabat yang telah mencapai tujuan dari Pendidikan Islam tersebut. Pada tahap awal Pendidikan Islam ini, pusat kegiatan Pendidikan Islam diselenggarakan secara sembunyi-sembunyi di rumah Arqam bin Abi Arqam. 5

Inilah pertama kalinya proses Pendidikan Islam mulai terlaksana. Ditempat inilah Rasulullah Saw mengajari para sahabat mengenai berbagai prinsip Islam. Rumah al-Arqam ini di Bukit Safa sebagai bukti sejarah tempat pengajaran Ilmu Pengetahuan dan amal saleh secara terpadu oleh seorang guru pelopor pertama yaitu Nabi Muhammad Saw. Proses pelaksanaan Pendidikan secara sembunyi disebabkan kondisi dan situasi belum Kondusif, dikhawatirkan proses Pendidikan Islam akan mengalami hambatan jika diketahui oleh kafir Quraisy yang pada awal kedatangan agama Islam yang notabene masih baru.

Kemudian pada tahap berikutnya, mulailah menyeru keluarga Bani Abdul Muthalib sesudah mendapatkan intruksi Q.S. Surat as-Syu'ara ayat 214. Perkataan Nabi Muhammad Saw diterima dengan baik dan dibenarkan bagi sebagian mereka, namun pada sebagiannya mendustakan, salah satunya ialah Abu Lahab yang memiliki hubungan dekat

${ }^{5}$ Haekal, Sejarah Hidup Muhammad, trans. oleh Ali Audah, vol. 1 (Jakarta: Tintamas, 1972), 30.

Al-Madrasah: Jurnal Ilmiah Pendidikan Madrasah Ibtidaiyah Vol. 6, No. 1, Januari-Maret 2022 
kekerabatan dengan Nabi yaitu paman Beliau, terlihat perilaku dan kebencian Abu Lahab Allah abadikan dalam firma-Nya di Surah al-Lahab. Selain itu ada juga dari kalangan Quraisy yang membantah dakwah Nabi Muhammad Saw, dikarenakan bertentangan dengan ajaran nenek moyang mereka. Sebagaimana dilema yang terjadi dalam dunia Pendidikan, di zaman Rasulullah Saw juga pernah terjadi, yaitu adanya suatu kelompok yang tidak mau menerima sama sekali materi Pendidikan dikarenakan faktor tertentu. Pendidikan Islam hanya berlaku secara efektif bagi yang ikhlas dan dengan sukarela memeluk Islam. Sebagai implementasinya untuk kondisi saat ini bahwa Pendidikan Islam selayaknya dilakukan bagi peserta didik siap dengan hati dan fikiran siap untuk menerima.

Beberapa riwayat menjelaskan bahwa banyak cara yang dilakukan oleh pemuka Quraisy untuk menghalangi dakwah Rasul di Mekkah, beberapa perilaku yang dilakukan untuk menghalangi dakwah Rasul ialah seperti ancaman, melontarkan tuduhan-tuduhan palsu, mengejek, menindas, menyindir, mengolok-olok, mencela, menghina sampai dengan gangguan puncaknya menargetkan pembunuhan kepada Rasulullah Saw. ${ }^{6}$ Namun, berbagai hambatan seperti itu mampu dilalui para sahabat yang tekadnya sudah kuat dalam Agama Islam. Para sahabat rela mendapatkan siksaan, hidup dalam penderitaan, keluarganya dibunuh dan hartanya dirampas demi membela Islam. Hal yang demikian mencerminkan bahwa Pendidikan Islam yang diajarkan Rasulullah Saw telah melekat disanubari kaum Muslimin. Sehingga pada puncaknya Rasulullah Saw dan para sahabat melaksanakan hijrah disebabkan level keamanan semakin kecil demi menyelamatkan para sahabat. Kemudian untuk tahap berikutnya Rasulullah Saw mendapat instruksi berupa wahyu supaya melaksanakan dakwah secara terang-terangan khususnya bagi penduduk Makkah.

\section{Penanaman nilai Pendidikan Islam secara terbuka (terang-terangan)}

Rasul mendapat ayat yang memerintahkan untuk berdakwah secara terbuka atau terang-terangan, maka sejak itulah Rasul mengajak segenap lapisan masyarakat untuk menerima hadirnya Islam di hati sanubari. Mulai dari golongan atas para bangsawan hingga golongan bawah para budak (hamba sahaya), tak luput juga sahabat dan kerabat Beliau serta orang-orang yang jauh maupun dekat. Diawali dengan berdakwah di sekitaran kota Mekkah hingga menyebar ke daerah dan kota-kota lain serta beberapa negeri. Tidak hanya

\footnotetext{
Ahmad M. Rizqullah, Biografi Rasulullah Sebuah Studi Analisis Berdasarkan Sumbersumber yang Otentik, trans. oleh Yessi M. Basyaruddin (Jakarta: Qisthi Press, 2005), 195.
}

Al-Madrasah: Jurnal Ilmiah Pendidikan Madrasah Ibtidaiyah Vol. 6, No. 1, Januari-Maret 2022 
melewatkan moment tertentu saat orang-orang yang jauh, pergi ke Mekkah untuk melaksanakan ibadah Haji, juga mendapat seruan dakwah Rasul untuk mau menerima Islam. $^{7}$ Seruan-seruan tersebut menurut juga merupakan tahapan Pendidikan yang dilakukan Rasulullah Saw kepada semua lapisan masyarakat yang berbeda-beda pemahaman. Walaupun tidak semua yang rela dan mau menerima. Namun, saat itu Rasulullah Saw sudah memiliki para sahabat yang telah ditempah dan sudah berproses dan sudah siap untuk ikut berkontribusi menanamkan nilai-nilai Pendidikan Islam kepada manusia lain yang masih membutuhkan.

Setiap fase dalam kemajuan untuk menyeru Agama Islam mempunyai tantangan tertentu, berbeda pada setiap tempat. Hal demikian dapat dilihat apabila telah melihat hasil penelitian dari berbagai unsur yang menyertai dalam proses dakwah pada fase dakwah di Mekkah dan Madinah. ${ }^{8}$ Sejarah mencatat bahwa periode tersebut dapat dikategorikan sebagai periode Makkah dan periode Madinah. Pada kurun masa dua periode tersebut terjadi berbagai bentuk Pendidikan dan secara mendasar bentuk Pendidikan Islam yang terjadi antara kedua periode tersebut berbeda corak, sistem, bentuk maupun isi Pendidikannya. Hal ini disebabkan oleh faktor, yaitu Kondisi kultural, Kondisi Pendidikan Islam di Makkah Secara kuantitas pemeluknya terkesan terhambat, disebabkan sosial masih berantakan, banyak pemuka Quraisy yang menentang ajaran Muhammad Saw. Hal tersebut didukung bahwa penduduk Makkah memiliki watak yang keras dan lebih menolak ajaran Muhammad. Sementara itu untuk Kota Madinah Pendidikan Islam berjalan cukup baik, hal ini karena penduduk Madinah menyambut Rasulullah Saw dan Para sahabat dengan suka cita, dikuatkan lagi bahwa Penduduk Kota Madinah masyarakatnya lebih lembut dan tenang.

\section{Pelaksanaan Pendidikan Islam di Makkah}

Rasulullah Saw saat melaksanakan dakwah berhadapan dengan nilai-nilai warisan Ibrahim yang sudah jauh melenceng dari ajaran murninya, menjadi fokus dalam ajaran tersebut ialah mengenai Tauhid. ${ }^{9}$ Namun saat Rasul diutus, ajaran tersebut sudah pudar dalam budaya masyarakat Arab Jahiliyah. Tuhan yang mereka sembah adalah patung

\footnotetext{
${ }^{7}$ M. Rizqullah, 86.

8 Shafiyur Rahman Al-Mubarakfury, Sirah Nabawiyah (Jakarta: Pustaka Al-Kautasar, 2010),

${ }^{9}$ Zuhairini, Sejarah Pendidikan Islam (Jakarta: Bumi Aksara, 1992), 23.
} 69.

Al-Madrasah: Jurnal Ilmiah Pendidikan Madrasah Ibtidaiyah Vol. 6, No. 1, Januari-Maret 2022 
berhala dan berbagai praktik kemusyirikan yang berbaur dengan ajaran tauhid. Oleh sebab itu Rasul diutus untuk mengembalikan ajaran terdahulu yaitu mengembalikan cahaya tauhid dalam kehidupan umat manusia umumnya dan yang pertama mendapat dakwah Rasul ialah masyarakat Arab jahiliyah. Pendidikan yang paling utama pada masa periode Mekkah ialah memurnikan ajaran tauhid. Penghayatan yang sifatnya esensial terhadap ketauhidan yang terdapat dalam Q.S al-Fatihah

Pendidikan tentang tauhid yang Nabi Muhammad Saw ajarkan kepada umatnya sangat bijaksana dengan menalarkan akal pikiran agar dapat menerima pengertian tauhid yang Beliau aplikasikan dalam kehidupan sehari-hari. Kemudian baru Rasul memberikan perintah kepada umatnya agar bisa mencontohnya. Seperti halnya wahyu turun secara bertahap Rasulullah Saw pun memberikan pelajaran tentang Islam secara bertahap juga, dengan tujuan agar para sahabat mengerti dan paham serta dapat mengamalkannya. Ini juga yang menjadi bagian dari hikmah bahwa ayat Alquran diturunkan secara bertahap.

Fase pendidikan Islam yang ada di Mekkah bisa dikatakan masih tergolong pada tahap pendidikan rendah, karena masyarakatnya masih minim yang bisa baca-tulis, dan juga para sahabat masih sangat asing terhadap ajaran Rasul. Dakwah yang diberikan Rasul menyesuaikan dengan keadaan dan suasana. Maka pada masa awal dakwah yang diberikan adalah masalah keimanan kemudian pendidikan terntang ibadah dan terakhir tentang akhlak. ${ }^{10}$ Berdasarkan pandangan dari 'Ulumul Quran untuk membedakan materi dakwah Rasul bisa terlihat pada surat yang diturunkan di kota Mekkah dengan ayat yang diturunkan di kota Madinah. ${ }^{11}$ Dengan menilik isi yang termuat dalam surah Makkiyah dan surah Madaniyyah maka akan terlihat isi oendidikan Islam pada fase Mekkah ataupun fase Madinah. Beberapa dasar yang tercatat dalam pendidikan Islam pada fase Makkah ialah:

a. Dakwah tentang keagamaan, ialah Rasulullah berdakwah kepada umat bahwa membaca dengan nama Allah semesta, tidak berbuat syirik dengan menyekutukan Allah dengan berhala, karena Allah Maha Besar dan Maha Pemurah, maka hilangkanlah berhala sejauh mungkin dalam sendi-sendi kehidupan,

10 Samsul NIzar, Sejarah Pendidikan Islam Menelusuri Jejak Sejarah Pendidikan Era Rasulullah Sampai Indonesia (Jakarta: Kencana Prenada Media Group, 2008), 12.

11 Khalil Manna Al-Qattan, Mabahis fi 'Ulumil Quran, trans. oleh Mudzakir (Jakarta: PT. Mitra Kerjaya Indonesia, 2004), 63.

Al-Madrasah: Jurnal Ilmiah Pendidikan Madrasah Ibtidaiyah Vol. 6, No. 1, Januari-Maret 2022 
b. Dakwah tentang 'Aqliyah dan Ilmiyah, ialah memberikan pelajaran tentang kejadian manusia berasal yaitu dimulai dari segumpal darah terus dijelaskan tentang kejadian alam semesta. Allah memberikan pelajaran yang demikian itu kepada siapa-siapa yang mau menyelidiki dan membahasnya, sedangkan orang-orang terdahulu belum mempelajarinya,

c. Dakwah tentang akhlak dan budi pekerti, Rasulullah Saw memberikan pelajaran kepada para sahabatnya tentang akhlak yang baik sesuai dengan ajaran tauhid,

d. Dakwah tentang pentingnya kesehatan (jasmani), ialah agar para sahabat bisa menjaga kebersihan, baik badan, pakaian maupun tempat tinggal. ${ }^{12}$

Rasul memiliki tugas menyampaikan pokok ajaran Islam yaitu menjelaskan tauhid dan mengajarkan Alquran secara sempurna, kemudian akan dilanjutkan secara turun temurun menjadi warisan kepada kaum muslimin agar dijadikan sebagai pegangan dan pedoman hidup. Ketika Rasul memberikan pelajaran Islam di kota Mekkah, ada beberapa kalangan yang sudah pandai baca-tulis. Diantaranya ialah 'Umar bin Khattab, 'Ali bi Abi Thalib, 'Usman bin Affan, Abu 'Ubaidah bin Jarrah, Talhan, Yazid bin Abi Sufyan, Abu Hudzaifah bin 'Utbah, Abu Sufyan bin Harb, Mu'awiyah bin Abu Sufyan dst. Adapun dari kalangan perempuan Hafsah, Ummi Kalsum binti 'Uqbah, 'Aisyah binti Sa'ad, al-syifak binti Abdullah al-Adawiyah dan Karimah binti al-Miqdad. Beberapa riwayat yang mengisahkan terdapat kuttab (seperti sekolah untuk anak-anak) yang mengajarkan membaca dan menulis. ${ }^{13}$ Namun demikian, hal tersebut belum merasuk dalam sendi-sendi masyarakat saat masa itu untuk menjadikan budaya baca tulis, kendati masyarakat Arab lebih cenderung dengan Syai'r (Puisi), astrologi dan pidato. ${ }^{14}$

Masyarakat Arab memiliki tradisi yang sangat pekat ialah budaya lisan, budaya ini menjadi warisan turun temurun. Mereka juga memiliki kebiasaan untuk menghafal Sya'ir (puisi). Memiliki kelebihan ingatan yang kuat seperti menghafal nasab atau garis keturunan, yang mana suku lain belum tentu bisa melakukannya. Masyarakat Arab mendapat tradisi menghafal nasab tersebut melalui lisan, maka dari itulah kemahiran untuk membaca dan menulis disinyalir merupakan hal yang tidak terlalu penting. Dari tradisi

\footnotetext{
${ }^{12}$ Mahmud Yunus, Sejarah Pendidikan Islam (Jakarta: Hidakarya Agung, 1997), 27.

13 Yunus, 28.

14 Syed Amer Ali, Api Islam: Sejarah Evolusi dan Cita-Cita Islam dengan Riwayat Hidup Nabi Muhammad Saw (Jakarta: Bulan Bintang, 1978), 548.
}

Al-Madrasah: Jurnal Ilmiah Pendidikan Madrasah Ibtidaiyah Vol. 6, No. 1, Januari-Maret 2022 
tersebut masyarakat Arab menjadi terkenal dengan kuatnya hafalan mereka. Nabi Muhammad Saw menyampaikan wahyu Alquran kepada sahabat dengan membacakan ayat tersebut sebagaimana yang Beliau terima dari Allah Swt. Hikmah diturunkannya Alquran secara bertahap ialah agar memudahkan Nabi Muhammad Saw untuk memberikan pendidikan kepada sahabat, sehingga mereka dapat menerima dan dapat menghafal secara bertahap. Kemudian Nabi Muhammad Saw menyuruh para sahabat yang sudah mahir menulis agar menuliskan apa yang dibacakan Rasul dari ayat Alquran dan dari hafalan para sahabat. Selanjutnya Beliau memberikan arahan dan ketetapan pada bagian-bagian dan urutan-urutan ayat yang baru diturunkan dipadukan dengan ayat yang diturunkan sebelumnya. Rasul juga menamai surah, tanda agar dapat membedakan antara satu surat dengan surat lainnya. Rasul juga mengarahkan agar lafadz basmallah diletakkan diawal setiap surat yang baru.

Rasulullah Saw saat berdakwah kepada para sahabatnya yang berada saat di kota Mekkah maupun saat sesudah hijrah di kota Madinah, beberapa strategi dakwah Nabi ialah Pertama, materi tentang tauhid dengan strategi dakwah Nabi adalah melalui tanya jawab. Jawaban yang diberikan Nabi bersandarkan dengan bukti-bukti ilmiah. Kedua, materi tentang ibadah dengan strategi dakwah Nabi memberikan demonstrasi beserta keteladanan agar dapat diikuti. Ketiga, materi tentang akhlak dengan strategi keteladanan, seperti Nabi Muhammad Saw dalam kehidupan sehari-hari Beliau memiliki kemuliaan dan Keagungan serta akhlak yang baik, berupa ucapan ataupun perbuatan. ${ }^{15}$

\section{Lembaga Pendidikan Islam Periode Makkah}

Seperti yang telah disampaikan di atas, dakwah Islam pada masa awal di sampaikan secara sembunyi-sembunyi di salah satu rumah sahabat yang bernama al-Arqam, rumah alArqam berada di bukit shafa dengan pintu rumahnya menghadap ke timur, dengan ukuran rumah sekitar $8 \times 4$ meter. ${ }^{16}$ Selain rumah sahabat yang dijadikan tempat dakwah, ada juga cara dakwahnya dengan cara Dor to dor (rumah ke rumah). Namun, pada dasarnya dakwah Rasulullah bukan hanya pada tempat, tapi juga dalam interaksi dengan sahabat Rasulullah selalu memberikan nasehat dan uswah dalam hal dan keadaan, dimanapun. Selain yang

\footnotetext{
15 NIzar, Sejarah Pendidikan Islam Menelusuri Jejak Sejarah Pendidikan Era Rasulullah Sampai Indonesia, 93.

16 M. Rizqullah, Biografi Rasulullah Sebuah Studi Analisis Berdasarkan Sumbersumber yang Otentik, 236.
}

Al-Madrasah: Jurnal Ilmiah Pendidikan Madrasah Ibtidaiyah Vol. 6, No. 1, Januari-Maret 2022 
demikian pada masa ini juga sudah berdiri kuttab semacam tempat baca tulis walaupun notabenenya masa itu diperuntukkan untuk kalangan anak-anak. Kuttab tersebut memberikan fungsi, Sebagai belajar tulis - baca dengan teks dasar berbagai puisi Arab, jenis kuttab pertama ini hanya mengajarkan tulis-baca selanjutnya mengalami pembaharuan lebih meningkat lagi dengan memasukkan kurikulum tulis-baca Alquran, dasar-dasar agama dan Ilmu Pengetahuan yang sifatnya umum.

Melalui Pendidikan yang dilakukan Rasulullah Saw yang begitu panjang selama kurun waktu 23 tahun mulai Rasulullah di Makkah sampai setelah beliau hijrah ke Makkah sampai setelah beliau hijrah ke Madinah, maka dapat terlihat bagaimana metode Pendidikan yang dicontohkan oleh Rasulullah Saw ketika menyampaikan ajaran tauhid Rasulullah memberikan gambaran yang memudahkan sahabat untuk memahaminya, ketika memberikan ajaran akhlak, beliau memberikan contoh tauladan yang baik. Kemudian metode lain yaitu ceramah, ketika Rasulullah Saw menerima wahyu beliau langsung menerangkannya kepada para sahabat secara perlahan, kemudian ada juga metode tanya jawab, metode diskusi, metode demonstrasi (ketika mencontohkan tata cara pelaksanaan ibadah) dan metode berkesinambungan yaitu Rasulullah melakukan Pendidikan secara terus menerus secara berkesinambungan. Metode Pendidikan yang dicontohkan Rasulullah tersebut bertujuan agar ajaran Islam bisa masuk dan diterima di kalangan orang-orang kafir, selain itu Rasulullah mengadakan pertemuan secara terus menerus, berusaha menyelamatkan kaum lemah yang tertindas oleh kekejaman orang kafir, membela diri jika dalam keadaan darurat dan sabar menanggung siksaan dan penindasan yang luar biasa demi menegakkan ajaran tauhid. Sebagaimana riwayat menyebutkan tentang membela diri dalam keadaan darurat terlihat ketika Sa'ad bin Abi Waqqas sedang shalat bersama beberapa sahabat Rasulullah Saw disebuah lorong Makkah tiba-tiba mereka dipergoki oleh sejumlah orang musyrikin. Orang-orang tersebut lalu mengancam dan mencela apa yang mereka lakukan sehingga terjadilah pertarungan, maka pada waktu itu catatan sejarah menuliskan bahwa itulah darah yang pertama kali ditumpahkan dalam Islam. ${ }^{17}$

Seluruh metode yang digunakan oleh Rasulullah Saw yang paling paten ialah metode keteladanan. Karena dapat mendidik dan memebrikan pelajaran langsung terhadap

\footnotetext{
Muhammad Munir Al-Ghadban, Manhaj Haraki Strategi Pergerakan dan Perjuangan Politik dalam Sirah Nabi SAW, trans. oleh Aunur Rafiq Shalih Tahmid (Jakarta: Rabbani Press, 1992), 64.
}

Al-Madrasah: Jurnal Ilmiah Pendidikan Madrasah Ibtidaiyah Vol. 6, No. 1, Januari-Maret 2022 
masyarakat. Rasulullah Saw sebagai model paripurna untuk kehidupan Muslim bisa dilihat dari dua tataran, ialah sebagai model personal dan sebagai model sosial. ${ }^{18}$ Dilihat dari model personal Rasulullah Saw memiliki gambaran yang mempunyai kepribadian dan akhlak yang mulia sedari kecil hingga dewasa, tentunya ini bisa dijadikan sebagai public figure. Berikutnya Rasulullah Saw menjadi model sosial dapat terlihat ketika Beliau memimpin dalam urusan sosial yang memiliki akhlak yang mewarnai kehidupan bermasyarakat.

\section{Implementasi Pendidikan Islam di Madinah}

Rasulullah Saw diperintahkan untuk hijrah dari Makkah ke Madinah tidak sekedar untuk mempertahankan diri dari ancaman atau hanya sekedar berpindah tempat, namun juga untuk mengatur dan menyusun strategi agar bisa menghadapi rintangan-rintangan berikutnya. Rasulullah Saw datang di kota Madinah bersama kaum muslimin disambut dengan riang gembira oleh penduduk Madinah dengan rasa persaudaraan yang tinggi. Saat berada di Kota Madinah dengan lingkungan baru dan tanpa tekanan oleh masyarakat Quraisy Mekkah. Dilingkungan ini Rasulullah dapat berakwah dan membina masyarakat dalam koridor Islami sehingga cahaya tauhid menampakkan sinarnya. Kemudian Rasul memberikan pelajaran atau dakwah tentang pendidikan, sosial dan politik. ${ }^{19}$

Namun, perlu digaris bawahi, tetap saja Pendidikan tauhid pada masa ini dikatakan sebagai materi yang sangat penting. Hal ini karena Pendidikan tauhid dan akhlak menjadi kurikulum atau materi dasar yang harus ditanamkan lebih awal kepada para sahabat, khususnya bagi sahabat pemula memeluk Islam sebagai pondasi utama. Ketika pondasi sudah kuat maka dengan sendirinya materi lainnya akan menyusul. Tidak jauh berbeda ketika dianalogikan dengan Pendidikan sekarang, bahwa kurikulum Pendidikan Islam sejatinya dijalankan secara sistematis. Tantangan perdana yang didapat Rasulullah Saw dan kaum muslimin (muhajirin) saat berada di kota Madinah ialah tempat tinggal. Sementara waktu kaum muslimin menginap dirumah kaum Anshor (masyarakat Madinah). Agar dapat menyebarkan ajaran Islam maka Rasul memerlukan tempat yang bisa digunakan menjadi

19 Arief Armai, Sejarah Pertumbuhan dan Perkembangan Lembaga Pendidikan Islam Klasik (Bandung: Angkasa, 2005), 135-36.
}

Al-Madrasah: Jurnal Ilmiah Pendidikan Madrasah Ibtidaiyah Vol. 6, No. 1, Januari-Maret 2022 
pusat kegiatan dakwah dan sekaligus sebagai ikon pemersatu diantar kaum Anshor dan Muhajirin.

Hal yang pertama Nabi Muhammad Saw lakukan ketika berada di kota Madinah ialah membangun Masjid yang bisa digunakan untuk tempat ibadah dan menyampaikan ajaran Islam. Masjid juga dijadikan pusat kegiatan membangun dan membina masyarakat baru. Di masjid juga tempat untuk bermusyawarah kaum muslimin, mendirikan sholat berjamaah, membaca Alquran, menjelaskan Ayat-ayat Alquran yang baru datang dan yang terdahulu.

Tantangan berikutnya yang harus Nabi Muhammad Saw selesaikan ialah membimbing dan menumbuhkan persatuan dan kesatuan masyarakat Islam yang baru berkembang menjadi satu kesatuan sosial dan satu kesatuan politik. Kaum Ansor dan kaum muhajirin yang memiliki latar belakang suku dan daerah yang berbeda-beda dan membawa adat istiadat yang berbeda sebelum Islam hadir, keduanya membentuk masyarakat yang penuh perselisihan dan perbedaan. Namun, ketika Islam hadir ditengah kebudayaan dan suku tersebut. Maka mereka menjadi bersatu dalam perbedaan, saling memahami perbedaan. Tidak hanya sampai disitu, tantangan berikutnya hadir dari sisi agama. Agama yang ada di kota Madinah beraneka ragam, ada agama yahudi yang terlebih dahulu ada disana, juga ada agama orang-orang madinah yang belum memeluk agama Islam. Hal ini tidaklah menutup kemungkinan bahwa mereka bisa saja berusaha untuk menghalangi dan juga memecah persatuan dan kesatuan masyarakat muslim. Setelah pembangunan mesjid dan masalah tempat tinggal sudah selesai Rasulullah Saw kemudian mulai meletakkan dasar-dasar terbentuknya masyarakat yang bersatu padu secara internal dan dari luar diakui serta disegani oleh masyarakat lainnya (sebagai satu kesatuan politik). Dasar-dasar tersebut antara lain:

1) Nabi Muhammad Saw mengikis habis sisa-sisa permusuhan dan pertentangan antar suku, dengan jalan mengikat tali persaudaraan diantara mereka. Tali persaudaraan tersebut ada yang diikatkan antara sesama kaum Muhajirin, kemudian diantara mereka dengan sengaja beliau persaudarakan dengan kaum Ansor seperti Abu Bakar dipersaudarakan dengan Khairiyah bin Zubeir, 'Umar dengan 'Itban bin Malik, Abu 'Ubaidah dengan Abdurrahman bin Auf serta Sa'ad bin Al-Rabi', 'Usman bin 'Affan 
dan 'Aus bin Sabit al-Munzir yang telah dipersaudarakan menjadi keluarga Bani alNajar, Talhah bin 'Ubaidillah dengan Ka'ab bin Malik dan seterusnya. ${ }^{20}$

2) Dalam memenuhi berbagai kebutuhan hidup sehari-hari, Nabi Muhammad Saw menganjurkan kaum Muhajirin untuk membuat usaha dan bekerja sesuai dengan skillnya, yang sanggup berdagang dianjurkan untuk melanjutkan usaha dagangnya, mampu bertani mengerjakan tanah-tanah milik kaum Ansor, Bagi yang miskin disediakan tempat disalah satu penjuru Mesjid sementara biaya hidup ditanggung dari harta kaum Muslimin yang mampu secara financial,

3) Kemudian sesudah turunnya syari'at zakat dan puasa, maka hal ini merupakan bentuk Pendidikan bagi masyarakat dalam tanggung jawab secara sosial, baik secara materil maupun moral. Dengan adanya zakat kehidupan sosial menjadi lebih baik dan terciptanya solidaritas tinggi.

4) Disyari'atkannya Shalat Jum'at secara berjama'ah, Salah satu kebijaksanaan yang sangat ampuh untuk mengumpulkan kaum Muslimin. Dengan pelaksanaan Shalat Jum'at tersebut semakin mudah dalam mengembangkan masyarakat Madinah sebab mendengar langsung arahan dan khutbah yang dipimpin Nabi Muhammad Saw.

Rasulullah Saw ketika sampai di kota Madinah yang memiliki banyak budaya berbeda, hal ini yang menjadi pekerjaan Rasul untuk menyatukan berbagai budaya yang berbeda memalui dokumen penting yang dikenal dengan Piagam Madinah. ${ }^{21}$ Melalui Piagam Madinah ini Rasul dapat mewujudkan masyarakat Madani yaitu masyarakat yang tenang, masyarakat yang harmonis dan masyarakat yang damai. Dakwah Islam saat di Kota Madinah ialah melanjutkan pendidikan yang ada di Kota Mekkah di mana pendidikan di kota Madinah lebih berkembang. Beberapa sahabat yang memiliki talenta dan mampu menyerap ilmu dengan baik saat diajar oleh Nabi Muhammad Saw, diberikan hak oleh untuk mengajar di berbagai wilayah kekuasaan Islam. ${ }^{22}$ Kendati saat itu belum ada ijazah seperti sekarang. Efek yang ditimbulkan ketika Rasul memberi hak untuk mengajar kepada para sahabatnya ialah semakin berkembangnya Islam di semenanjung Arab karena para

20 A Guillame, The Life of Muhammad, a Translationn of Ibnu Ishaq 's Sirat Rasul Allah (Inggris:Oxford University Press, 1970), 234.

21 Mahmudunnasir, Islam Konsepsi dan Sejarahnya, trans. oleh Adang Afandi (Bandung: PT. Remaja Rosda Karya, 2005), 90.

${ }^{22}$ Nata Abuddin, Sejarah Pendidikan Islam (Jakarta: Media Kencana Group, 2011), 89.

Al-Madrasah: Jurnal Ilmiah Pendidikan Madrasah Ibtidaiyah Vol. 6, No. 1, Januari-Maret 2022 
sahabat terus berdakwah dan memperkenalkan ajaran tauhid yang di bawa oleh Rasulullah Saw.

\section{Lembaga Pendidikan Islam Periode Madinah}

Membangun Masjid merupakan hal yang pertama Rasulullah Saw lakukan ketika hijrah ke kota Madinah, di mana masjid dijadikan sebagai pusat pendidikan dan dakwah ajaran Islam. Periode ini mengenalkan masjid dengan suatu lembaga pendidikan. Menilik sejarahnya bahwa masjid yang pertama dibangun ialah Masjid Quba. Masjid Quba terletak kurang lebih 2 mil dari kota Madinah, adapun sebutan lain untuk Masjid Quba ialah Masjid Taqwa. Firman Allah Swt dalam Q.S at-Taubah: 108. Pada fase ini Masjidlah tempat yang dijadikan sebagai sarana dalam mengembangkan pendidikan dan dakwah secara berkelanjutan. Di bagian Masjid ada dikenal tempat yang dinamai al-suffah. Ini merupakan tempat di mana berkumpulnya orang-orang fakir dan miskin untuk menuntut ilmu pemahaman tentang Islam.

Masjid pada masa sekarang dikenal sebagai tempat mencari ilmu pengetahuan yang tertua dalam Islam. Masjid dibangun sejak masa Rasulullah Saw dan tersebar ke seluruh penjuru negeri Arab berbarengan dengan disebarkannya agama Islam dipenjuru negeri. Masjid menjadi pusat pendidikan Alquran dan dasar-dasar agama ketika masa Rasulullah Saw, selain berfungsi sebagai tempat untuk melaksanakan ibadah, masjid juga digunakan untuk aktivitas kegiatan sosial-politik, pengembangan ekonomi dan sebagainya. ${ }^{23}$

Tidak terlalu berbeda metode yang digunakan Nabi Muhammad Saw dalam dakwah ketika berada di kota Mekkah hampir sama Rasul gunakan juga untuk berdakwah di Kota Madinah. Kendatipun cakupan ruang lingkup pendidikan di kota Madinah memiliki ranah yang luas seperti mencakup masalah sosial-politik. Najib dalam buku al-Hasyimi ${ }^{24}$ menjelaskan beberapa metode pendidikan Islam yang digunakan oleh Nabi Muhammad Saw ialah sebagai berikut:

a) Metode teguran langsung, pernah Nabi Muhammad Saw memberikan pelajaran saat mengajarkan tata cara makan yang baik,

b) Metode sindiran, pernah Nabi Muhammad Saw memberikan amalan yang baik agar bisa diikuti oleh sahabat,

23 Fahmi Hasan Asmah, Sejarah Filsafat Pendidikan Islam, trans. oleh Ibrahim (Jakarta: Bulan Bintang, 1997), 33.

${ }^{24}$ Abdul Hamid, Mendidik Ala Rasulullah (Jakarta: Pustaka Azam, 2001), 113.

Al-Madrasah: Jurnal Ilmiah Pendidikan Madrasah Ibtidaiyah Vol. 6, No. 1, Januari-Maret 2022 
c) Metode perbandingan, Nabi Muhammad Saw sering menceritakan orang-orang terdahulu dan orang-orang masa sekarang dengan cara dibandingkan,

d) Metode pemukulan (memberikan nilai pendidikan), Rasulullah Saw saat ingin membiasakan anak-anak agar terbiasa shalat di usia-usia tertentu,

e) Metode kata isyarat, saat mengajar pernah Rasulullah Saw menunjukkan tangan Beliau ketika memberikan pelajaran kepada sahabat,

f) Metode ceramah, ini sangat sering digunakan Rasulullah Saw kepada para sahabat baik ketika khutbah ataupun ketika berkumpul dengan sahabat,

g) Metode keteladanan, Rasulullah Saw memberikan contoh nyata kepada para sahabat agar bisa diikuti.

Dalam riwayat lain ditemukan bahwa metode Pendidikan yang dilakukan oleh Rasulullah ketika memecahkan berbagai masalah yang sering muncul di tengah masyarakat dengan metode diskusi atau dialog. Hal ini sangat efektif sebagai problem solving jika terjadi kesalahpahaman antara satu dengan yang lainnya. Baik mengenai masalah Agama, sosial, ekonomi dan sampai politik. Pada tahap berikutnya metode Pendidikan Islam yang sudah diimplementasikan mengalami perkembangan, salah satunya dengan metode halaqah-halaqah (lingkaran) yang dilakukan beberapa pusat Pendidikan Islam yaitu Mesjid as-Suffah dan Mesjid Quba. Metode halaqah adalah metode Pendidikan di mana peserta didik yang lebih tinggi pengetahuannya duduk dengan Syekh, sedangkan peserta didik yang tingkatan ilmu pengetahuannya rendah secara otomatis akan duduk sedikit lebih jauh, sementara berjuang belajar keras agar dapat mengubah posisinya dalam perjalanan Pendidikannya. ${ }^{25}$

\section{KESIMPULAN}

Pendidikan Islam terus berjalan sampai tibanya hari kiamat nanti, kemudian estafet dakwah Islam dilanjutkan kepada Khulafaurrasyidin dan masa-masa sesudahnya. Melalui segala bentuk kegiatan dan Praktik Pendidikan yang sudah dilakukan Rasulullah Saw kepada umat Islam dimulai dari dakwahnya di Makkah sampai dakwahnya di Madinah maka tergambarlah beberapa hal:

\footnotetext{
${ }^{25}$ Hasan Asari, Menyikapi Zaman Keemasan Islam (Bandung: Citapustaka Media Perintis, 2007),
} 49.

Al-Madrasah: Jurnal Ilmiah Pendidikan Madrasah Ibtidaiyah Vol. 6, No. 1, Januari-Maret 2022 
a. Dakwah Nabi bertujuan hanya agar mentauhidkan

b. Tujuan Pendidikan, semata-mata hanya untuk metauhidkan, beribadah dan mengharapkan ridha Allah Swt,

c. Pendidikan yang diajarkan oleh Rasulullah Saw ialah tentang tauhid, akhlak, mu'amalah dan beberapa ilmu yang temuat dalam Alquran dan Sunnah,

d. Metode pendidikan yang diberikan Nabi Muhammad Saw sangat beraneka ragam seperti: metode teguruan, metode sindiran, metode perbandingan, metode pukulan (dengan syarat tidak berbekas dan tidak pada bagian yang dilarang), metode menggunakan isyarat, metode ceramah, dan metode keteladanan. Ada juga metode yang digunakan Rasul seperti metode tanya jawab, metode pemisalan, metode kisahkisah, metode pembiasaan dan metode hafalan (menghafal ayat Alquran).

e. Lembaga Pendidikan yang pertama kali digunakan pada masa dakwah Rasulullah Saw yaitu dari rumah ke rumah seperti rumah Arqam bin Abi Arqam yang menjadi central lembaga pertama, selanjutnya sesudah Rasul dan para sahabat hijrah ke Madinah barulah kemudian dibangun sebuah Mesjid yang menjadi pusat Pendidikan dan pengajaran Islam. Selain itu ada juga kuttab sebagai lembaga tulis-baca berbagai syair yang pada perkembangannya menjadi tempat mempelajari Alquran dan berbagai ilmu lainnya.

\section{DAFTAR PUSTAKA}

A Guillame. The Life of Muhammad, a Translationn of Ibnu Ishaq 's Sirat Rasul Allah. Inggris: Oxford University Press, 1970.

A Syalabi. Sejarah dan Kebudayaan Islam. Jakarta: Al-Husna Zikra, 1997.

Abuddin, Nata. Sejarah Pendidikan Islam. Jakarta: Media Kencana Group, 2011.

Amer Ali, Syed. Api Islam: Sejarah Evolusi dan Cita-Cita Islam dengan Riwayat Hidup Nabi Muhammad Saw. Jakarta: Bulan Bintang, 1978.

Armai, Arief. Sejarah Pertumbuhan dan Perkembangan Lembaga Pendidikan Islam Klasik. Bandung: Angkasa, 2005.

Asari, Hasan. Esai-Esai Sejarah, Pendidikan dan Kehidupan. Bandung: Citapustaka Media, 2009.

—. Menyikap Zaman Keemasan Islam. Bandung: Citapustaka Media Perintis, 2007.

Asrori, Ahmad. Reorientasi Ilmu Pendidikan Islam Dari Paradigma Klasik Hingga Kontemporer. Yogyakarta: Cetta Media, 2014.

Haekal. Sejarah Hidup Muhammad. Diterjemahkan oleh Ali Audah. Vol. 1. Jakarta: Tintamas, 1972.

Al-Madrasah: Jurnal Ilmiah Pendidikan Madrasah Ibtidaiyah Vol. 6, No. 1, Januari-Maret 2022 
Hamid, Abdul. Mendidik Ala Rasulullah. Jakarta: Pustaka Azam, 2001.

Hasan Asmah, Fahmi. Sejarah Filsafat Pendidikan Islam. Diterjemahkan oleh Ibrahim. Jakarta: Bulan Bintang, 1997.

Kurniawan, Syamsul. Pendidikan Karakter. Yogyakarta: Ar-ruzz Media, 2013.

M. Rizqullah, Ahmad. Biografi Rasulullah Sebuah Studi Analisis Berdasarkan Sumber-sumber yang Otentik. Diterjemahkan oleh Yessi M. Basyaruddin. Jakarta: Qisthi Press, 2005.

Mahmudunnasir. Islam Konsepsi dan Sejarahnya. Diterjemahkan oleh Adang Afandi. Bandung: PT. Remaja Rosda Karya, 2005.

Manna Al-Qattan, Khalil. Mabahis fi 'Ulumil Quran. Diterjemahkan oleh Mudzakir. Jakarta: PT. Mitra Kerjaya Indonesia, 2004.

Muliawan. Ilmu Pendidikan Islam. Jakarta: Raja Grafindo Persada, 2015.

Munir Al-Ghadban, Muhammad. Manhaj Haraki Strategi Pergerakan dan Perjuangan Politik dalam Sirah Nabi SAW. Diterjemahkan oleh Aunur Rafiq Shalih Tahmid. Jakarta: Rabbani Press, 1992.

NIzar, Samsul. Sejarah Pendidikan Islam Menelusuri Jejak Sejarah Pendidikan Era Rasulullah Sampai Indonesia. Jakarta: Kencana Prenada Media Group, 2008.

Rahman Al-Mubarakfury, Shafiyur. Sirah Nabawiyah. Jakarta: Pustaka Al-Kautasar, 2010.

Yunus, Mahmud. Sejarah Pendidikan Islam. Jakarta: Hidakarya Agung, 1997.

Zuhairini. Sejarah Pendidikan Islam. Jakarta: Bumi Aksara, 1992.

Al-Madrasah: Jurnal Ilmiah Pendidikan Madrasah Ibtidaiyah Vol. 6, No. 1, Januari-Maret 2022 